\title{
Genetic and molecular biology of systemic lupus erythematosus among Iranian patients: an overview
}

\author{
Meisam Gachpazan ', Iman Akhlaghipour², Hamid Reza Rahimi' ', Ehsan Saburi ${ }^{1}$, Majid Mojarrad', \\ Mohammad Reza Abbaszadegan ${ }^{1}$ and Meysam Moghbeli ${ }^{1^{*}}$ [D
}

\begin{abstract}
Background: Systemic lupus erythematosus (SLE) is a clinicopathologically heterogeneous chronic autoimmune disorder affecting different organs and tissues. It has been reported that there is an increasing rate of SLE incidence among Iranian population. Moreover, the Iranian SLE patients have more severe clinical manifestations compared with other countries. Therefore, it is required to introduce novel methods for the early detection of SLE in this population. Various environmental and genetic factors are involved in SLE progression.

Main body: In present review we have summarized all of the reported genes which have been associated with clinicopathological features of SLE among Iranian patients.

Conclusions: Apart from the reported cytokines and chemokines, it was interestingly observed that the apoptosis related genes and non-coding RNAs were the most reported genetic abnormalities associated with SLE progression among Iranians. This review clarifies the genetics and molecular biology of SLE progression among Iranian cases. Moreover, this review paves the way of introducing an efficient panel of genetic markers for the early detection and better management of SLE in this population.
\end{abstract}

Keywords: Systemic lupus erythematosus, Genetic, Diagnosis, Marker, Iran

\section{Background}

Autoimmune disorders are associated with immune system attack to the body's own organs, tissues, and cells $[1,2]$. They have an increasing frequency in industrialized countries. Systemic lupus erythematosus (SLE) is a heterogeneous autoimmune disorder characterized by antinuclear, anti-double-stranded DNA, and antiphospholipid antibodies [3]. The incidence rate of SLE varies in different geographical regions from 1 to 10 per 100,000 person annually [4]. North America has the highest rate of SLE incidence $(23.2 / 100,000)$ and prevalence

\footnotetext{
*Correspondence: Meysam_moghbeli@yahoo.com; moghbelim@mums.ac.ir ${ }^{1}$ Department of Medical Genetics and Molecular Medicine, School of Medicine, Mashhad University of Medical Sciences, Mashhad, Iran Full list of author information is available at the end of the article
}

$(241 / 100,000)[5,6]$, while Africa and Ukraine have the lowest incidences $(0.3 / 100,000$ persons/year) $[7,8]$. In Asia, the Chinese and Asian Indians have higher SLE prevalence in comparison with Arabs [9-12]. Various clinical symptoms are observed in SLE patients such as renal failure, arthritis, thrombosis, and neurologic complications. There are different environmental and genetic risk factors associated with SLE etiology. SLE is more prevalent in women (about nine times more than men) and more diagnosed between 15 and 44 years old [4]. Smoking [13], alcohol consumption [14], metals [15], air pollution [16], obesity [17], diet [18], infections [19], pesticides [20], and silica [21] are environmental risk factors associated with SLE. Genetic factors have also important roles during SLE progression which are mainly associated with combined effect of various genes. Single-nucleotide 
polymorphisms (SNPs) that are associated with SLE pathogenesis are also mainly located in noncoding DNA sequences of immune system genes [22]. The prevalence of SLE in Iran as a middle-east country is reported 40 per 100,000 persons. SLE has more severe symptoms among Iranian patients compared with European Caucasians. It seems that the higher severity of SLE among Iranians can be associated with some environmental risk factors such as ethnic and diet in which Iranians as a non-white population has higher SLE severity compared with European population (white). Moreover, low carbohydrate/fiber, high protein/fat intakes, and micronutrients deficiencies among Iranians can also be associated with high severity of SLE in this population [23-27]. Poor sleep quality and vitamin $\mathrm{D}$ deficiency has been reported among Iranian SLE patients $[28,29]$. Regarding the severe clinical complications among Iranian SLE patients, it is required to introduce a diagnostic panel of genetic markers for the early detection of SLE. Therefore, in present review we have summarized all of the reported genes with significant effects on SLE progression among Iranian cases. We also categorized them based on their cell and molecular functions to clarify the biology of SLE among Iranian population. Moreover, we categorized the reported factors based on their outcomes into genetic/epigenetic aberrations and cytokines/chemokine abnormalities (Tables 1, 2).

\section{Main text Cytokines}

Cytokines are soluble glycoproteins that function in autocrine/paracrine states between leukocytes and other cells which are involved in leukocyte growth and migration [31, 32]. Moreover, various other biological processes such as angiogenesis and inflammation are associated with cytokines production via lymphocytes, monocytes, keratinocytes, and endothelial cells [33]. IL-1 is a pro inflammatory cytokine involved in autoimmune responses [34]. The IL-1 receptor antagonist (IL-1RN) is a suppressor of IL-1 activity [35]. A significant correlation has been observed between IL-1RN rs315952 polymorphism and SLE among Iranian patients in which the CT genotype was protective. Patients with hematological symptoms had significantly higher frequency of rs 315952 $\mathrm{T}$ allele. There was also a significant decreased frequency of rs315952 CT genotype in SLE cases compared with controls [36]. There was a significant correlation between IL-2 serum level and SLE disease activity among Iranian cases. The serum level of IL-2 was significantly correlated with Prednisone consumption [37].

IL-4 is a pleiotropic cytokine produced by various cells such as T cells, basophils, and NK cells [38, 39] which has pivotal role in regulating the T helper 2 (Th2) development [40, 41]. It has been shown that there were significant increased frequencies of $\mathrm{C}$ allele at -33 and -590 as well as $\mathrm{T}$ allele at -1098 SNPs among a sample of SLE cases compared with controls. There were also increased frequencies of $33 \mathrm{CC}, 590 \mathrm{CC}$, and $1098 \mathrm{TT}$ genotypes, while decreased frequencies of $33 \mathrm{TC}, 590$ TC, and 1098 TG genotypes. IL-4 gene polymorphisms may lead to the reduced frequencies of TTC, GCC and TTT haplotypes, while there was significant increased rate of TCC haplotype in SLE cases [42].

IL-10 is a cytokine mainly secreted by monocytes and B lymphocytes which suppresses the other pro-inflammatory cytokines in activated macrophages and $\mathrm{T}$ lymphocytes [43, 44]. IL-10 is involved in SLE pathogenesis through induction of B lymphocytes proliferation and autoantibodies production by damaged organs $[45,46]$. It has been reported that the GG genotype of IL-10 (1082) and CC genotype of IL-10 (819) polymorphisms were correlated with increased SLE susceptibility among Iranian patients. There were IL-10 plasma up regulations in CC and AA genotype carriers of -592 and -1082, respectively. The CC and TT genotype carriers at -592 and - 819 regions respectively had also increased SLEDAI score [47]. Disturbed immune tolerance and T/B lymphocytes activation results in production of autoantibodies. V-Set Domain Containing T Cell Activation Inhibitor 1 (VTCN1) is an inhibitor of T cell responses, cell-cycle progression, and cytokine production [48-51] that can be up regulated by IL-10 and IL-6 [52]. The STAT4 is a transcription factor induced by IL-12 and IL-23 which has a pivotal function in Th1 and Th17 differentiation [53-57]. Therefore, STAT4 can also be involved in SLE pathogenesis [57]. It has been reported that there was a significant correlation between rs7574865TT and GT genotypes and risk of SLE in a sample of Iranian subjects [58].

$\mathrm{T}$ helper and regulatory $\mathrm{T}$ cells are the main regulators of inflammation during SLE progression. Th1 cells related cytokines are associated with cell-mediated immunity [59], whereas Th17 cells are involved in organ damage through IL-17 production [60]. It has been reported that there was increased IL-17 levels in a sample of Iranian SLE patients receiving glucocorticoid treatments compared with newly diagnosed and healthy cases. There was also a significant direct association between IL-17 and IFN- $\gamma$ plasma levels while a negative association between IL-17 and IL-10 cytokines [61]. Glomerulonephritis is an important organ involvement in SLE which is associated with poor prognosis and end-stage disease [62]. Regulatory $\mathrm{T}$ cells have critical role in regulation of unwanted immune responses and can be involved in lupus nephritis (LN) progression $[63,64]$. Th17 cells as effector T helper cells have been observed in damaged organs of SLE cases [65]. Up regulations of Th1 and Th17 cytokines induced 
Table 1 All of the genetic aberrations with significant effects on clinicopathological features of SLE among Iranian patients

\begin{tabular}{|c|c|c|c|c|}
\hline Study (et al.) & Year & Gene & Population & Results \\
\hline Tahmasebi [36] & 2013 & IL-1RN & $\begin{array}{l}213 \mathrm{NC}^{\mathrm{a}} \\
207 \mathrm{SLE}^{\mathrm{b}}\end{array}$ & Polymorphism was correlated with SLE progression \\
\hline Mahmoudi [42] & 2014 & $\mathrm{IL}-4$ & $\begin{array}{l}140 \mathrm{NC} \\
59 \mathrm{SLE}\end{array}$ & Polymorphism was correlated with SLE progression \\
\hline Mohammadi [47] & 2019 & IL-10 & $\begin{array}{l}131 \mathrm{NC} \\
116 \mathrm{SLE}\end{array}$ & Polymorphism was correlated with SLE progression \\
\hline Mirkazemi [58] & 2013 & STAT4 & $\begin{array}{l}281 \mathrm{NC} \\
280 \mathrm{SLE}\end{array}$ & Polymorphism was correlated with SLE progression \\
\hline Alesaeidi [76] & 2015 & MECP2 & $\begin{array}{l}392 \mathrm{NC} \\
492 \mathrm{SLE}\end{array}$ & Polymorphism was correlated with SLE progression \\
\hline Sahebari [79] & 2010 & FAS & $\begin{array}{l}50 \mathrm{NC} \\
114 \mathrm{SLE}\end{array}$ & Different serum levels of Fas between cases and controls \\
\hline Moudi [82] & 2013 & FAS, FASL & $\begin{array}{l}149 \mathrm{NC} \\
106 \mathrm{SLE}\end{array}$ & Polymorphism was correlated with SLE progression \\
\hline Araste [86] & 2010 & FAS & $\begin{array}{l}249 \mathrm{NC} \\
212 \mathrm{SLE}\end{array}$ & Polymorphism was correlated with SLE progression \\
\hline Fathi [90] & 2020 & PDCD1 & $\begin{array}{l}564 \mathrm{NC} \\
253 \mathrm{SLE}\end{array}$ & Polymorphism was correlated with SLE progression \\
\hline Mahmoudi [91] & 2015 & PDCD1 & $\begin{array}{l}50 \mathrm{NC} \\
202 \mathrm{SLE}\end{array}$ & Polymorphism was correlated with SLE progression \\
\hline Rajabi [102] & 2012 & TNFSF4, TRAF2 & $\begin{array}{l}57 \mathrm{NC} \\
57 \mathrm{SLE}\end{array}$ & Increased and decreased levels of TNFSF4 and TRAF2 expressions respectively \\
\hline Namazi [107] & 2017 & APRIL & $\begin{array}{l}64 \mathrm{NC} \\
60 \mathrm{SLE}\end{array}$ & Increased serum APRIL levels \\
\hline Salimi [110] & 2018 & ERa & $\begin{array}{l}186 \mathrm{NC} \\
170 \mathrm{SLE}\end{array}$ & Polymorphism was correlated with SLE progression \\
\hline Shojaa [114] & 2017 & CTLA-4 & $\begin{array}{l}304 \mathrm{NC} \\
180 \mathrm{SLE}\end{array}$ & Polymorphism was correlated with SLE progression \\
\hline Salimi [118] & 2014 & $\mathrm{XRCC} 1$ & $\begin{array}{l}180 \mathrm{NC} \\
163 \mathrm{SLE}\end{array}$ & Polymorphism was correlated with SLE progression \\
\hline Jahantigh [122] & 2015 & $\mathrm{XRCC} 5, \mathrm{XRCC7}$ & $\begin{array}{l}180 \mathrm{NC} \\
163 \mathrm{SLE}\end{array}$ & Polymorphism was correlated with SLE progression \\
\hline Salimi [131] & 2016 & Osteopontin & $\begin{array}{l}180 \mathrm{NC} \\
163 \mathrm{SLE}\end{array}$ & Polymorphism was correlated with SLE progression \\
\hline Mirfeizi [135] & 2012 & UMCP-1 & 67 SLE & Increased UMCP-1 levels \\
\hline Noroozinia [143] & 2016 & CD34 & 73 SLE & CD34 expression was associated with activity index \\
\hline Sharifipour [147] & 2013 & LCN2 & 52 SLE & Increased urinary LCN2/creatinine level \\
\hline Bahrehmand [156] & 2012 & MMP-2 & $\begin{array}{l}101 \mathrm{NC} \\
109 \mathrm{SLE}\end{array}$ & Polymorphism was correlated with SLE progression \\
\hline Bahrami [175] & 2020 & PTPN22 & $\begin{array}{l}93 \mathrm{NC} \\
55 \mathrm{SLE}\end{array}$ & Polymorphism was correlated with SLE progression \\
\hline Sandoughi [185] & 2016 & eNOS & $\begin{array}{l}194 \mathrm{NC} \\
106 \mathrm{SLE}\end{array}$ & Polymorphism was correlated with SLE progression \\
\hline Bahrehmand [197] & 2013 & PON1 & $\begin{array}{l}83 \mathrm{NC} \\
109 \mathrm{SLE}\end{array}$ & Polymorphism was correlated with SLE progression \\
\hline Tanhapour [199] & 2018 & ApoE, PON1 & $\begin{array}{l}117 \mathrm{NC} \\
101 \mathrm{SLE}\end{array}$ & Polymorphism was correlated with SLE progression \\
\hline Khoshmirsafa [203] & 2019 & miR-16, miR-21, and miR-155 & $\begin{array}{l}30 \mathrm{NC} \\
55 \mathrm{SLE}\end{array}$ & $\begin{array}{l}\text { Increased expression of miR-16, miR-21, and miR-155 while miR-141 down } \\
\text { regulation }\end{array}$ \\
\hline Vahed [206] & 2018 & miR-125a, miR-142-3p, miR-146a & $\begin{array}{l}26 \mathrm{NC} \\
26 \mathrm{SLE}\end{array}$ & $\begin{array}{l}\text { Increased circulating miR-125a and miR-146a levels while reduced level of } \\
\text { circulating miR-142-3p }\end{array}$ \\
\hline Nakhjavani [209] & 2019 & miR-21, miR-150, miR-423 & $\begin{array}{l}26 \mathrm{NC} \\
26 \mathrm{SLE}\end{array}$ & $\begin{array}{l}\text { Reduced levels of circulating miR-150 while increased levels of circulating miR- } \\
21 \text { and miR-423 }\end{array}$ \\
\hline Akhtari [214] & 2016 & $\mathrm{KIR}, \mathrm{HLA}$ & $\begin{array}{l}273 \mathrm{NC} \\
230 \mathrm{SLE}\end{array}$ & Polymorphism was correlated with SLE progression \\
\hline Rezaieyazdi [215] & 2008 & $\mathrm{HLA}$ & $\begin{array}{l}83 \mathrm{NC} \\
40 \mathrm{SLE}\end{array}$ & Polymorphism was correlated with SLE progression \\
\hline
\end{tabular}


Table 1 (continued)

a Normal control (NC)

b Systemic lupus erythematosus (SLE)

Table 2 All of the reported cytokines/chemokines abnormalities during SLE progression among Iranian patients

\begin{tabular}{|c|c|c|c|c|}
\hline Study (et al.) & Year & Gene & Population & Results \\
\hline Sedighi [37] & 2014 & $\| \mathrm{L}-2$ & $\begin{array}{l}73 \mathrm{NC}^{\mathrm{a}} \\
73 \mathrm{SLE}^{\mathrm{b}}\end{array}$ & IL-2 was significantly correlated with Prednisone consumption \\
\hline Mohammadi [61] & 2019 & $\mathrm{IL}-17$ & $\begin{array}{l}20 \mathrm{NC} \\
40 \mathrm{SLE}\end{array}$ & Increased IL-17 levels is SLE patients receiving glucocorticoids \\
\hline Rastin [66] & 2016 & $\mathrm{IL}-6, \mathrm{IL}-17, \mathrm{IFN}-\gamma$ & 40 SLE & $\mathrm{IL}-17, \mathrm{IL}-6$, and IFN- $\gamma$ up regulations \\
\hline Aghdashi [69] & 2013 & $\mathrm{IL}-18$ & $\begin{array}{l}25 \mathrm{NC} \\
25 \mathrm{SLE}\end{array}$ & Serum levels of IL-18 were correlated with platelet counts and C3 levels \\
\hline Jafari-Nakhjavani [71] & 2016 & IL-18 & $\begin{array}{l}50 \mathrm{NC} \\
113 \mathrm{SLE}\end{array}$ & Increased serum levels of IL-18 \\
\hline Loghman [73] & 2016 & Adiponectin & 50 SLE & Increased urinary levels of adiponectin \\
\hline Sahebari [80] & 2012 & Fas, IL-18 & $\begin{array}{l}50 \mathrm{NC} \\
114 \mathrm{SLE}\end{array}$ & Increased serum levels of Fas and IL-18 \\
\hline Hatef [81] & 2013 & IL-18, Fas & $\begin{array}{l}46 \mathrm{NC} \\
32 \mathrm{SLE}\end{array}$ & Increased serum levels of Fas and IL-18 \\
\hline Abediazar [128] & 2019 & CXCL10 & $\begin{array}{l}39 \mathrm{NC} \\
25 \mathrm{SLE}\end{array}$ & Increased levels of CXCL10 \\
\hline Hajialilo [142] & 2018 & VCAM-1, ET-1 & $\begin{array}{l}40 \mathrm{NC} \\
60 \mathrm{SLE}\end{array}$ & Up regulations of serum VCAM-1 and ET-1 \\
\hline Yazdanpanah [167] & 2017 & TLR3, TLR7, TLR9 & $\begin{array}{l}20 \mathrm{NC} \\
20 \mathrm{SLE}\end{array}$ & TLR7 and TLR9 up-regulations \\
\hline Mortezagholi [169] & 2016 & TLR9 & $\begin{array}{l}38 \mathrm{NC} \\
35 \mathrm{SLE}\end{array}$ & Increased expression of TLR9 \\
\hline
\end{tabular}

a Normal control (NC)

b Systemic lupus erythematosus (SLE)

nephrogenic conditions in LN. It has been reported that there were IL-17, IL-6, and interferon gamma (IFN- $\gamma$ ) up regulations in class IV glomerulonephritis SLE in comparison with non-nephritis SLE subjects in a sample of Iranian population [66].

IL-18 has a pivotal role in progression of cutaneous lupus erythematosus (CLE) and SLE $[67,68]$. It has been reported that there were significant direct associations between serum levels of IL-18 and platelet counts among a sample of Iranian SLE patients with high disease activity, while inverse correlation between IL-18 and C3 levels [69]. One of the feasible mechanisms of SLE progression is Th1 and Th2 imbalanced that leads in B lymphocyte cell activity. IL-18 has a key function in Th1 response toward toxic shocks. It induces INF- $\gamma$ production by $\mathrm{T}$ and NK cells and proliferation of activated T cells [70]. It has been shown that there were significant increased serum levels of IL-18 among Iranian SLE cases compared with healthy subjects. Serum levels of IL-18 were also associated with SLE disease activity index (SLEDAI) and high activity indexes. Active SLE patients had also higher levels of IL-18 compared with chronic cases. Moreover, the SLE cases with renal involvement had significantly higher serum level of IL-18 compared with cases without renal complication [71].

Adiponectin is an adipocyte-derived cytokine involved in renal complications of SLE [72]. There were significant increased urinary levels of adiponectin in Iranian SLE patients with renal complication compared with cases lacking renal involvement [73]. IFN- $\gamma$ is a soluble cytokine produced by various cells such as Th cells, macrophages, and NK cells which is involved in NK induction and leukocyte migration. Methyl CpG binding protein 2 (MECP2) recruits the histone deacetylase to promoter regions of target genes which induces heterochromatin formation and transcriptional inhibition [74]. It can also suppresses the gene expression via DNA methyltransferase1 (DNMT1) recruitment. MECP2 down regulates the IFN- $\gamma$ secretion by Th cells that results in a partial immune suppression [75]. It has been reported that there were significant correlations between rs1734787 and rs1734791 polymorphisms of MECP2 and SLE progression among Iranian patients in which the $\mathrm{C}$ allele of rs1734787 and $\mathrm{T}$ allele of rs1734791 polymorphisms 
increased the SLE risk. Moreover, there were significant frequencies of CTAT and AAAT haplotypes in cases and controls, respectively [76].

\section{Apoptosis and DNA repair}

Fas/APO-1 belongs to the tumor necrosis factor (TNF) family of proteins that play a significant role in cell death, peripheral tolerance, and autoimmune response [77]. FAS is expressed normally at a low level on resting cells, while is highly expressed by activated T cells [78]. A significant different serum levels of Fas has been observed between a sample of Iranian SLE cases and control group [79]. Another study has been reported that there were increased serum levels of Fas and IL-18 in a sample of Iranian SLE patients compared with controls which were also associated with disease activity and erythrocyte sedimentation rate (ESR) [80]. Increased serum Fas and IL-18 levels were also significantly observed in patients with proteinuria in comparison with cases without proteinuria [81]. A significant different frequency of FAS A-670G AA genotype compared with GG genotype has been shown between Iranian SLE patients and controls. The SLE patients had also significantly increased frequency of A allele compared with $G$ allele. Regarding the FASL C-844T polymorphism, CC genotype and C allele were significantly more frequent in SLE patients compared with healthy subjects. The AA/CC genotypes of FAS A-670G/FASL C-844T increased SLE susceptibility more than other genotypes [82]. The interaction of Fas and FasL results in apoptosis [83]. Soluble fas (sFas) is a variant without transmembrane domain [84] which is observed in supernatants of $\mathrm{B}$ and $\mathrm{T}$ cell lines [85]. The promoter region polymorphisms of the Fas have been assessed among Iranian SLE patients which showed significant higher frequencies of $1377 \mathrm{G}$ allele and GG genotype in patients compared with controls. There were also reduced frequencies of $-1377-670(\mathrm{~A}-\mathrm{G}) /-1377-670$ (A-G) haplotype among patients compared with healthy cases. Moreover, patients had significantly increased levels of sFas and Fas ligand compared with controls. There was lower levels of anti-SSB/La in-670GG genotype carriers. Therefore, Fas promoter polymorphisms were suggested as risk factors of SLE among Iranian patients [86].

Programmed cell death 1 (PD-1) is an immunosuppressive factor associated with autoimmune disorders $[87,88]$. It has a significant role in regulation of $\mathrm{T}$ cells function [89]. The correlation between PDCD1 SNPs and SLE progression was assessed among Iranian population. It has been reported that there was significant increased frequency of PD1.5 C/C genotype in SLE patients compared with healthy cases, while the PD1.5 C/T and T/T genotypes frequencies were reduced in SLE patients. There was also significant correlations between GACT and GGCC haplotypes of PDCD1 and SLE susceptibility, while GGCT was protective during SLE progression [90]. Another group has been reported that there was a significant inverse correlation between PD1.1 GG genotype and juvenile-onset SLE (JSLE) susceptibility among a sub population of Iranian cases. The PD-1.1 A allele was also more frequent among cases in comparison with controls [91].

TNF superfamily member 4 (TNFSF4) has critical roles in regulation of $\mathrm{T}$-cell proliferation and activation which promotes $\mathrm{CD} 4+\mathrm{T}$ cells survival in inflammation sites [92]. It also induces naive CD4 $+\mathrm{T}$ cells for the secretion of IL-4, IL-5, and IL-13 [93, 94]. Moreover, TNFSF4 stimulates B-cell proliferation that results in cell hyperactivity in autoimmune disorders [95-97]. The TNF and TNF receptor have important roles in lymphocyte apoptosis during immune regulation [98]. TNF-R signaling is mediated by TNF-R-associated factor 2 (TRAF2) that is an adaptor protein and ubiquitin ligase [99]. TRAF2 is also associated with non-canonical NF-kB pathway through TNF- $\alpha$ [100]. There is an interaction between TNFSF4 and TRAF2 to modulate apoptosis through NF-KB pathway which is involved in T-cell-mediated autoimmunity [101]. There was increased and decreased levels of TNFSF4 and TRAF2 expressions respectively in PBMCs of Iranian SLE patients compared with controls. A positive association was also between TNFSF4 expression levels and atherosclerotic symptoms in SLE patients. TRAF2 down regulation was also associated with renal involvement and atherosclerosis. The SLE cases with severe clinical symptoms had lower levels of TRAF2 expression which showed a negative association between SLEDAI and TRAF2 down regulation [102].

A proliferation-inducing ligand (APRIL) is belonged to the TNF superfamily involved in B lymphocyte proliferation and antibody production [103]. Heparin sulfate have been also reported as APRIL receptor [104-106]. There was significant increased serum APRIL levels in a sample of Iranian children with SLE compared with healthy cases [107]. Estrogen inhibits the apoptosis in PBMCs of SLE patients and ER $\alpha$ up regulation have been observed among SLE cases $[108,109]$. It has been reported that the CC/GG and TC/AA genotypes and TT haplotype of ERaPvuII and XbaI polymorphisms were correlated with increased risk of SLE among Iranian subjects [110].

Cytotoxic lymphocyte antigen-4 (CTLA-4) has critical roles in regulation of $\mathrm{T}$ cell activation, apoptosis, and peripheral tolerance $[111,112]$. CTLA-4 up regulation in active SLE patients shows a key role during SLE progression [113]. There was an association between CTLA4$318 \mathrm{C} / \mathrm{T}$ polymorphism and SLE pathogenesis among a sub population of Iranian cases in which the CC genotype was significantly correlated with SLE susceptibility, 
while the $\mathrm{CT}$ genotype and $\mathrm{T}$ allele were more frequent among healthy cases [114].

Deregulation of DNA repair system results in DNA breaks that produces immunogenic antigens and induces autoimmune response [115]. XRCC1 is one of the members of base excision repair (BER) system [116] involved in repair of DNA damages caused by various factors such as active oxygen and alkylating agents [117]. It has been reported that there were significant decreased frequency of XRCC1 Arg/Gln genotype in a sample of Iranian SLE patients compared with controls which had also decreased frequency in malar rash positive compared with SLE cases without malar marsh [118]. Homologous recombination (HR) and non-homologous end joining (NHEJ) are the main mechanisms of double-strand break (DSB) repairs $[119,120]$. Autoantibodies against $\mathrm{Ku}$ as one of the members of NHEJ are reported in SLE patients [121]. It has been shown that there were significant correlations between XRCC7 6721G > T and XRCC5 VNTR polymorphisms and SLE susceptibility in a sample of Iranian subjects. The 0R allele of XRCC5 VNTR polymorphism was more frequent in SLE patients in comparison with controls which introduced $\mathrm{OR}$ allele as a risk factor of SLE [122].

\section{Chemokines and adhesion factors}

Lupus nephritis (LN) is observed in about $35 \%$ of early diagnosed SLE patients and up to $60 \%$ of patients after 10 years [123]. CXCL10 is a chemokine produced by several cells such as fibroblasts and monocytes which is associated with angiogenesis reduction and T cells migration to the inflammatory sites [124, 125]. The CXCL10 up regulation has been observed in autoimmune disorders [126]. The vasculoprotective role of vitamin D is associated with decreased CXCL10 secretion by macrophages in SLE patients [127]. There were significant elevated and decreased levels of CXCL10 and vitamin D respectively in a sample of Iranian SLE patients in comparison with controls and SLE cases without nephritis. CXCL10 was also associated with SLE disease activity index (SLEDAI) and renal activity [128].

Osteopontin (OPN) is a chemokine with pivotal roles in regulation of bone biology, inflammation, and immune response. It induces and suppresses the Th1 and Th2 responses, respectively [129]. CD44 is the most important receptor of OPN to regulate cellular chemotaxis and adhesion [130]. There was a significant increased frequency of OPN rs1126616CT genotype among a group of Iranian LN patients compared with controls. LN cases had also higher frequency of rs1126616TT genotype compared with controls. Moreover, increased serum OPN level was observed in SLE patients with LN and joint complications in comparison with SLE cases without these symptoms [131].

Urinary monocyte chemoattractant protein 1 (UMCP1 ) is an efficient marker of renal complication among lupus cases which is expressed by several renal cells such as endothelial and mesangial cells [132, 133]. It is involved in monocyte and $\mathrm{T}$ cells recruitment and activation in acute and chronic inflammation [134]. It has been reported that there were significant elevated UMCP-1 levels in a group of Iranian LN patients compared with LN negative cases [135].

VCAM-1 is belonged to the immunoglobulin-like superfamily produced by various cells such as endothelial cells and macrophages, which stimulates leukocytes adhesion to the vascular endothelium [136-139]. Endothelin-1 (ET-1) is also an endothelial cell-derived factor associated with endothelial dysfunction which has a key role during SLE progression [140, 141]. There were significant up regulations of serum VCAM-1 and ET-1 in a sample of Iranian SLE cases compared with healthy subjects [142]. CD34 is an intercellular adhesion factors expressed in various cells such as hematopoietic cells, endothelial cells, and fibroblasts. CD34 expression was observed in all of a sample of Iranian LN patients which had an inverse association with activity index. Therefore, CD34 can be protective in LN cases. High CD34 expression was also observed in patients with higher SBP and lower WBC count [143].

Renal involvement is an important reason of mortality in SLE patients that is still a big challenge of management because of heterogeneity and complicated course [144]. The Lipocalin-2 (LCN2) is a transporter expressed in neutrophils and renal cells that is up regulated during inflammation [145]. LCN2 promotes cell migration through chemokines up regulations in brain in which the LCN2 amplifies neuro inflammation and inflammatory cells recruitment through CXCL10 up regulation in CNS cells [146]. It has been observed that there were increased urinary LCN2/creatinine level in Iranian LN patients compared with cases without nephritis which was also significantly associated with proteinuria [147].

Coronary heart disease (CVD) and stroke are the main reasons of SLE related deaths [148-150]. Matrix metallopeptidases (MMPs) are zinc-dependent enzymes associated with degradation of extracellular matrixes $[151,152]$. MMP-2 is produced by macrophages and has critical roles in SLE progression [152-154]. CCL11 and CXCL12 can up regulate the MMP-2 through PI3K/Akt signaling pathway [155]. A significant correlation has been observed between MMP-2 G1575A polymorphism and CVD progression in Iranian SLE patients. Both MMP-2 $1575 \mathrm{~A}$ allele and G/ApA/A genotype increased SLE susceptibility and CVD progression compared with G/G 
genotype. SLE patients had also significantly increased rate of G1575A allele compared with controls. Moreover, increased serum levels of MMP-2 and neoptrin were observed among SLE patients with CVD in comparison with patients without CVD [156].

\section{Toll-like receptors}

It has been reported that the abnormal induction of innate immunity through toll-like receptors (TLRs) has an important role during SLE progression [157-159]. The nucleic acids and immune factors are the most common auto antigens in SLE patients which promote innate immune responses through TLRs [160, 161]. TLR3, TLR8, and TLR7 are involved in RNA molecules detection, whereas the TLR9 identifies un-methylated CpG islands [160]. Endosomal TLRs can also be associated with recognition of self-nucleic acids produced following tissue damage and infections [162, 163]. TLRs commitment by PAMPs/DAMPS can activate self-reactive B and $T$ cells which promotes the SLE progression $[164,165]$. Decreased serum levels of Vitamin D have been observed in active phase of SLE [166]. It has been reported that there were TLR7 and TLR9 up-regulations in the PBMCs of Iranian SLE compared with control cases. Vitamin D3 also reduced the TLR3, TLR7, and TLR9 expressions in PBMCs of SLE cases in comparison with healthy subjects [167]. B cells have critical functions in pathogenesis of SLE in which their deregulation results in production of auto-antibodies [168]. TLR binding with specific ligands up regulate the pro inflammatory cytokines in autoimmune disease [160]. There was significant increased expression of TLR9 in CD4+,CD8+T, and CD19+ B lymphocytes of SLE patients compared with control cases among Iranian population [169].

PTPN22 is a tyrosine phosphatase associated with negative regulation of T-cell activation [170]. It has an important role in up-regulation of type 1 IFNs following TLR binding in myeloid cells that is involved in suppression of inflammatory arthritis [171]. The PTPN22 polymorphisms have been reported in autoimmune disorders such as SLE, type 1 diabetes, and rheumatoid arthritis [172-174]. The rs1310182 AA and rs12760457 TT genotypes of PTPN22 were significantly correlated with PSLE among Iranian patients [175]. NO is a free radical produced by NO synthetases (NOS) [176]. NO has a key role in various cellular processes such as $\mathrm{T}$ lymphocyte activation, signal transduction [177], and apoptosis [178]. Endothelial NOS regulates TLR4-mediated IL-6 production through a NO-independent signaling [179].NO production by monocytes plays a pivotal function in $\mathrm{T}$ cell deregulation and continuous mitochondrial hyperpolarization in SLE patients [180, 181]. Vascular dysfunction in SLE patients is correlated with anti-endothelial cell antibody (AECA) [182, 183]. NO stimulates the cell death in endothelial cells through AECA [184]. It has been reported that there was a significant correlation between intron 4 VNTR polymorphism of eNOS and SLE progression in a sub population of Iranian patients in which SLE cases had higher frequencies of a allele and ba and aa genotypes compared with controls [185].

\section{Antioxidant agents}

Various environmental risk factors such as UV and xenobiotic compounds have pivotal roles during SLE progression [186]. Deregulation of antioxidant system results in elevated reactive oxygen species (ROS) during SLE progression [187-189]. Glutathione S-transferases (GSTs) are involved in detoxification of carcinogenic compounds through glutathione binding [190, 191]. GSTM1 and GSTP1 are associated with detoxification of polycyclic aromatic hydrocarbons, whereas the GSTT1 detoxifies simple hydrocarbons. They can also reduce the ROS levels which is a critical cell process for DNA maintenances toward oxidative damages [192,193]. There was a significant different frequency of GSTT1 null genotype between SLE cases and healthy subjects among a sub population of Iranian cases. GSTT1 null/GSTM1null/GSTP1 Ile/Val genotypes increased SLE susceptibility in this population [194]. Paraoxonase-1 (PON1) hydrolyzes lipid peroxides to maintain LDL against the oxidation. PON1 as an antioxidant that reduces the LDL oxidation is a critical regulator of atherosclerosis $[195,196]$. It has been observed that there was a correlation between PON1 55 M/M genotype and SLE susceptibility in a sample of Iranian SLE cases. PON1 $55 \mathrm{M} / \mathrm{M}$ genotype significantly increased the risk of SLE in comparison with L/L genotype carriers. There was also higher frequency of $55 \mathrm{M} / \mathrm{M}$ genotype in SLE patients with hypertension compared with cases without hypertension. Since, the M/M genotype carriers had high levels of neopterin and LDL-C, they had increased risk of hypertension [197]. Apolipoprotein E (ApoE) has also key roles in $\mathrm{T}$ lymphocyte proliferation and immune responses [198]. It has been observed that the ApoE4 and PON-55M alleles increased SLE susceptibility in a sample of Iranian patients. Neopterin and MDA had also higher serum levels in SLE patients with ApoE $\varepsilon 3 / \varepsilon 4$ and $\varepsilon 3 / \varepsilon 3$ genotypes in comparison with controls [199].

\section{Non-coding RNAs}

MicroRNAs (miRNAs) are a super family of noncoding RNAs (ncRNAs) with pivotal roles in immune responses and SLE pathogenesis. They are involved in lupus progression through deregulation of lymphocyte function, TLRs, and NF- $\kappa B$ signaling pathway [200]. MicroRNA deregulations in $\mathrm{T}$ and $\mathrm{B}$ cells have been 
reported during SLE progression toward LN [201, 202]. There were significant increased expressions of miR16, miR-21, and miR-155 while miR-141 down regulation in a sample of Iranian SLE patients compared with controls. MiR-21 and miR-155 had significantly higher levels of expressions in active LN compared with inactive LN patients. There was also an inverse association between miR-155 and C3/C4 serum levels [203]. CCL5 is an inflammatory chemokine that can be up regulated in SLE patients following the KLF13 suppression by miR125a [204]. The miR-142-3p regulates the $C D 4+T$ and $\mathrm{CD} 4+\mathrm{CD} 25+$ Treg cells functions that can be associated with SLE progression through B cell hyper stimulation [205]. It has been reported that there were increased circulating miR-125a and miR-146a levels among a sub population of Iranian LN cases compared with controls. There was also a reduced level of circulating miR-142-3p in LN patients compared with controls. Moreover, miR142-3p levels were significantly correlated with disease activity index [206]. MiR-21 and miR-150 are involved in immune responses via targeting PDCD4 and c-MYC, respectively [207, 208]. Reduced levels of circulating miR-150 has been shown among Iranian LN patients which showed active EMT and renal fibrosis. There were also significant increased levels of circulating miR-21 and miR-423 in a sample of Iranian LN patients in comparison with controls [209].

\section{Human leukocyte antigens}

Human leukocyte antigen (HLA) system has a critical role in regulation of innate and adaptive immunity through antigen presentation of intracellular and extracellular peptides. Natural killer (NK) cells regulate the activity of T lymphocytes and dendritic cells and lymphocyte-related autoimmune responses [210, 211]. Killer cell immunoglobulin (Ig)-like receptors (KIR) are important factors expressed by NK cells which identify HLA class I ligands [212, 213]. KIR and HLA polymorphisms were assessed in a sample of Iranian SLE cases that showed reduced frequency of HLA-A-Bw4 in SLE patients. The KIR3DL1p; HLA-B-Bw4Thr80p and KIR2DS1p; HLA-C2p carriers had significantly higher hematological and renal complications. Male carriers of KIR3DP1p had also significant increased prevalence of renal disorders [214]. The HLADQB1 variation was also assessed in a sample of Iranian SLE patients and controls that showed a significant correlation between HLADQ6 ("0601-"0609) and SLE. There was also decreased frequency of DQ7 ("0301*0304) in SLE patients compared with controls. Moreover, high frequency of DQ5-DQ6 was observed in SLE patients. The DQ6 was the common HLA DQB1 allele correlated with SLE susceptibility among Iranians [215].

\section{Conclusions}

SLE is a chronic autoimmune disorder with a rising prevalence among Iranian population. However, there was not any report about the genetics of SLE in this population. Regarding the critical role of genetic factors during SLE progression, it is required to clarify the molecular biology and genetics of SLE. Therefore, we summarized all of the genes associated with clinicopathological features of SLE which have been reported among Iranian patients. For the first time, it was interestingly observed that the apoptotic related genes and non-coding RNAs have critical roles during SLE progression among Iranians. This review paves the way of introducing a diagnostic panel of genetic markers for the early detection and better management of SLE among Iranian population.

\section{Abbreviations}

SLE: Systemic lupus erythematosus; SNPs: Single-nucleotide polymorphisms: VTCN1: V-set domain containing T cell activation inhibitor 1; IFN-Y: Interferon gamma; SLEDAI: SLE disease activity index; MECP2: Methyl CpG binding protein 2; TNF: Tumor necrosis factor; ESR: Erythrocyte sedimentation rate; JSLE: Juvenile-onset SLE; UMCP-1: Urinary monocyte chemoattractant protein 1; MMPs: Matrix metallopeptidases; TLRs: Toll-like receptors; NOS: NO synthetases; AECA: Anti-endothelial cell antibody; sFas: Soluble fas; PD-1: Programmed cell death 1; TRAF2: TNF-R-associated factor 2; APRIL: A proliferationinducing ligand; CTLA-4: Cytotoxic lymphocyte antigen-4; BER: Base excision repair; DSBs: Double-strand breaks; HR: Homologous recombination; NHEJ: Non-homologous end joining; IL-1 RN: IL-1 receptor antagonist; sIL-2R: Soluble IL-2 receptor; Th2: T helper 2; CLE: Cutaneous lupus erythematosus; IFNY: Interferon gamma; DNMT1: DNA methyltransferase1; HLA: Human leukocyte antigen; KIR: Killer cell immunoglobulin (Ig)-like receptor; ROS: Reactive oxygen species; GSTs: Glutathione S-transferases; PON1: Paraoxonase-1; ApoE: Apolipoprotein E; LN: Lupus nephritis; OPN: Osteopontin; LCN2: Lipocalin-2; CVD: Coronary heart disease; miRNAs: MicroRNAs; ncRNAs: Non-coding RNAs.

\section{Acknowledgements}

Not applicable.

Author's contributions

$M G, I A, H R R, E S, M R A$, and MMojarrad were involved in search strategy and drafting. MMoghbeli supervised the project and revised and edited the manuscript. All authors read and approved the final manuscript.

\section{Funding}

Not applicable.

\section{Availability of data and materials}

The datasets used and/or analyzed during the current study are available from the corresponding author on reasonable request.

Ethics approval and consent to participate

Not applicable.

Consent for publication

Not applicable.

\section{Competing interests}

The authors declare that they have no competing interests.

\section{Author details}

${ }^{1}$ Department of Medical Genetics and Molecular Medicine, School of Medicine, Mashhad University of Medical Sciences, Mashhad, Iran. ${ }^{2}$ Student Research Committee, Faculty of Medicine, Mashhad University of Medical Sciences, Mashhad, Iran. 
Received: 27 May 2020 Accepted: 9 October 2020

Published online: 30 January 2021

\section{References}

1. Fardi Golyan F, et al. Novel mutation in AIRE gene with autoimmune polyendocrine syndrome type 1. Immunobiology. 2019;224(6):728-33.

2. Moghbeli M. Genetic and molecular biology of multiple sclerosis among iranian patients: an overview. Cell Mol Neurobiol. 2020:40(1):65-85.

3. Rose NR. Prediction and prevention of autoimmune disease in the $21 \mathrm{st}$ century: a review and preview. Am J Epidemiol. 2016;183(5):403-6.

4. Pons-Estel GJ, et al. Understanding the epidemiology and progression of systemic lupus erythematosus. Semin Arthritis Rheum. 2010:39(4):257-68.

5. Feldman $\mathrm{CH}$, et al. Epidemiology and sociodemographics of systemic lupus erythematosus and lupus nephritis among US adults with Medicaid coverage, 2000-2004. Arthritis Rheum. 2013;65(3):753-63.

6. Ward M. Prevalence of physician-diagnosed systemic lupus erythematosus in the united states: results from the Third National Health and Nutrition Examination Survey. J Women's Health. 2002;2004(13):713-8.

7. Nasonov $\mathrm{E}$, et al. The prevalence and incidence of systemic lupus erythematosus (SLE) in selected cities from three Commonwealth of Independent States countries (the Russian Federation, Ukraine and Kazakhstan). Lupus. 2014;23(2):213-9.

8. Taylor HG, Stein CM. Systemic lupus erythematosus in Zimbabwe. Ann Rheum Dis. 1986;45(8):645-8.

9. Feng PH, Boey ML. Systemic lupus erythematosus in Chinese: the Singapore experience. Rheumatol Int. 1982;2(4):151-4.

10. Frank AO. Apparent predisposition to systemic lupus erythematosus in Chinese patients in West Malaysia. Ann Rheum Dis. 1980;39(3):266-9.

11. Houman $\mathrm{MH}$, et al. Systemic lupus erythematosus in Tunisia: demographic and clinical analysis of 100 patients. Lupus. 2004;13(3):204-11.

12. Samanta A, et al. The prevalence of diagnosed systemic lupus erythematosus in whites and Indian Asian immigrants in Leicester city, UK. Br J Rheumatol. 1992;31(10):679-82.

13. Takvorian SU, Merola JF, Costenbader KH. Cigarette smoking, alcohol consumption and risk of systemic lupus erythematosus. Lupus. 2014:23(6):537-44.

14. Barbhaiya $M$, et al. Influence of alcohol consumption on the risk of systemic lupus erythematosus among women in the Nurses' Health Study Cohorts. Arthritis Care Res (Hoboken). 2017;69(3):384-92.

15. Cooper GS, et al. Occupational and environmental exposures and risk of systemic lupus erythematosus: silica, sunlight, solvents. Rheumatology (Oxford). 2010:49(11):2172-80.

16. Bernatsky $S$, et al. Fine particulate air pollution and systemic autoimmune rheumatic disease in two Canadian provinces. Environ Res. 2016;146:85-91.

17. Tedeschi SK, et al. Obesity and the risk of systemic lupus erythematosus among women in the Nurses' Health Studies. Semin Arthritis Rheum. 2017;47(3):376-83.

18. Mu Q, Zhang H, Luo XM. SLE: another autoimmune disorder influenced by microbes and diet? Front Immunol. 2015;6:608.

19. Draborg A, Izarzugaza JM, Houen G. How compelling are the data for Epstein-Barr virus being a trigger for systemic lupus and other autoimmune diseases? Curr Opin Rheumatol. 2016;28(4):398-404.

20. Parks CG, D'Aloisio AA, Sandler DP. Early life factors associated with adult-onset systemic lupus erythematosus in women. Front Immunol. 2016;7:103.

21. Parks CG, De Roos AJ. Pesticides, chemical and industrial exposures in relation to systemic lupus erythematosus. Lupus. 2014;23(6):527-36.

22. Harley JB, et al. The genetics of human systemic lupus erythematosus. Curr Opin Immunol. 1998;10(6):690-6.

23. Davatchi F, et al. WHO-ILAR COPCORD Study (stage 1, urban study) in Iran. J Rheumatol. 2008:35(7):1384

24. Akbarian M, et al. Systemic lupus erythematosus in Iran: a study of 2280 patients over 33 years. Int J Rheum Dis. 2010;13(4):374-9.

25. Lundberg A, Akesson A, Akesson B. Dietary intake and nutritional status in patients with systemic sclerosis. Ann Rheum Dis. 1992;51(10):1143-8.
26. Mayen $\mathrm{A}-\mathrm{L}$, et al. Socioeconomic determinants of dietary patterns in low-and middle-income countries: a systematic review. Am J Clin Nutr. 2014;100(6):1520-31.

27. Mok M, LiW. Do Asian patients have worse lupus? Lupus. 2010:19(12):1384-90.

28. Bonakdar ZS, et al. Vitamin D deficiency and its association with disease activity in new cases of systemic lupus erythematosus. Lupus. 2011;20(11):1155-60

29. Mirbagher $L$, et al. Sleep quality in women with systemic lupus erythematosus: contributing factors and effects on health-related quality of life. Int J Rheum Dis. 2016;19(3):305-11.

30. Rezaieyazdi Z, et al. Investigation of the association between carotid artery intima-media thickness (IMT) and cardiac risk factors in patients with lupus erythematosus. Curr Rheumatol Rev. 2019;16:125-33.

31. Tsokos GC. Systemic lupus erythematosus. N Engl J Med. 2011;365(22):2110-21.

32. Bagheri $\vee$, et al. Cytokine networks and their association with Helicobacter pylori infection in gastric carcinoma. J Cell Physiol. 2018;233(4):2791-803.

33. Commins SP, Borish L, Steinke JW. Immunologic messenger molecules: cytokines, interferons, and chemokines. J Allergy Clin Immunol. 2010;125(2):S53-72

34. Dinarello C. The IL-1 family and inflammatory diseases. Clin Exp Rheumatol. 2002;20(5Suppl/27):S1-13.

35. Dripps DJ, et al. Interleukin-1 receptor antagonist binds to the type II interleukin-1 receptor on B cells and neutrophils. J Biol Chem. 1991:266(30):20311-5.

36. Tahmasebi Z, et al. Interleukin-1 gene cluster and IL-1 receptor polymorphisms in Iranian patients with systemic lupus erythematosus. Rheumatol Int. 2013;33(10):2591-6.

37. Sedighi $\mathrm{S}$, et al. Relationship between serum level of interleukin-2 in patients with systemic lupus erythematosus and disease activity in comparison with control group. J Clin Diagn Res JCDR. 2014;8(7):MC16.

38. Midgley A, et al. The role of neutrophil apoptosis in juvenile-onset systemic lupus erythematosus. Arthritis Rheum Off J Am Coll Rheumatol. 2009:60(8):2390-401

39. Sule $S$, et al. Abnormal production of pro-and anti-inflammatory cytokines by lupus monocytes in response to apoptotic cells. PLoS ONE. 2011;6(3):e17495.

40. Mosmann TR, Coffman R. TH1 and TH2 cells: different patterns of lymphokine secretion lead to different functional properties. Annu Rev Immunol. 1989:7(1):145-73.

41. Nelms K, et al. The IL-4 receptor: signaling mechanisms and biologic functions. Annu Rev Immunol. 1999;17(1):701-38.

42. Mahmoudi M, et al. Interleukin-4 single nucleotide polymorphisms in juvenile systemic lupus erythematosus. Int J Immunogenet. 2014:41(6):512-7

43. Beebe AM, Cua DJ, de Waal Malefyt R. The role of interleukin-10 in autoimmune disease: systemic lupus erythematosus (SLE) and multiple sclerosis (MS). Cytokine Growth Fact Rev. 2002;13(45):403-12.

44. Groux H, Cottrez F. The complex role of interleukin-10 in autoimmunity. J Autoimmun. 2003;20(4):281-5.

45. Dörner T, Jacobi AM, Lipsky PE. B cells in autoimmunity. Arthritis Res Ther. 2009; 11 (5):247.

46. Peng $\mathrm{H}$, et al. Role of interleukin-10 and interleukin-10 receptor in systemic lupus erythematosus. Clin Rheumatol. 2013;32(9):1255-66.

47. Mohammadi S, et al. Interleukin 10 gene promoter polymorphisms (rs1800896, rs1800871 and rs1800872) and haplotypes are associated with the activity of systemic lupus erythematosus and IL 10 levels in an Iranian population. Int J Immunogenet. 2019;46(1):20-30.

48. Sica $\mathrm{GL}$, et al. B7-H4, a molecule of the B7 family, negatively regulates $T$ cell immunity. Immunity. 2003:18(6):849-61.

49. Prasad DV, et al. B7S1, a novel B7 family member that negatively regulates T cell activation. Immunity. 2003;18(6):863-73.

50. Pawar $\mathrm{R}$, et al. B 7x/B 7-H 4 modulates the adaptive immune response and ameliorates renal injury in antibody-mediated nephritis. Clin Exp Immunol. 2015;179(2):329-43.

51. Zang $X$, et al. B7x: a widely expressed B7 family member that inhibits T cell activation. Proc Natl Acad Sci. 2003;100(18):10388-92.

52. Che F, et al. Novel B7-H4-mediated crosstalk between human nonHodgkin lymphoma cells and tumor-associated macrophages leads 
to immune evasion via secretion of IL-6 and IL-10. Cancer Immunol Immunother. 2017;66(6):717-29.

53. Farrar JD, et al. Recruitment of Stat 4 to the human interferon- $\alpha / \beta$ receptor requires activated Stat2. J Biol Chem. 2000;275(4):2693-7.

54. Morinobu A, et al. STAT4 serine phosphorylation is critical for IL12 -induced IFN- $\gamma$ production but not for cell proliferation. Proc Natl Acad Sci. 2002:99(19):12281-6.

55. Lund RJ, et al. Early target genes of IL-12 and STAT4 signaling in th cells. J Immunol. 2004:172(11):6775-82.

56. O'Malley JT, et al. STAT4 isoforms differentially regulate Th1 cytokine production and the severity of inflammatory bowel disease. J Immunol. 2008;181(7):5062-70.

57. Kobayashi S, et al. Association of STAT4 with susceptibility to rheumatoid arthritis and systemic lupus erythematosus in the Japanese population. Arthritis Rheum Off J Am Coll Rheumatol. 2008;58(7):1940-6.

58. Mirkazemi S, et al. Association of STAT4 rs7574865 with susceptibility to systemic lupus erythematosus in Iranian population. Inflammation. 2013;36(6): 1548-52.

59. Theofilopoulos AN, et al. The role of IFN-gamma in systemic lupus erythematosus: a challenge to the Th1/Th2 paradigm in autoimmunity. Arthritis Res Ther. 2001;3(3):136.

60. Nalbandian A, Crispin J, Tsokos G. Interleukin-17 and systemic lupus erythematosus: current concepts. Clin Exp Immunol. 2009;157(2):209-15.

61. Mohammadi S, Sedighi S, Memarian A. IL-17 is aberrantly overexpressed among under-treatment systemic lupus erythematosus patients. Iran J Pathol. 2019:14(3):236.

62. Schwartz MM, et al. The prognosis and pathogenesis of severe lupus glomerulonephritis. Nephrol Dial Transplant. 2008;23(4):1298-306.

63. Sakaguchi S. Naturally arising CD4 + regulatory T cells for immunologic self-tolerance and negative control of immune responses. Annu Rev Immunol. 2004;22:531-62.

64. Yang J, et al. Th17 and natural Treg cell population dynamics in systemic lupus erythematosus. Arthritis Rheum. 2009;60(5):1472-83.

65. Chen D, et al. The potential role of Th17 cells and Th17-related cytokines in the pathogenesis of lupus nephritis. Lupus. 2012;21(13):1385-96.

66. Rastin $\mathrm{M}$ et al. Expression of T Helper 17 and regulatory $T$ cell cytokines and molecules in glomerulonephritis class IV systemic lupus erythematosus. 2016

67. Shimizu C, et al. High circulating levels of interleukin-18 binding protein indicate the severity of glomerular involvement in systemic lupus erythematosus. Mod Rheumatol. 2012;22(1):73-9.

68. Dinarello CA. Interleukin-18 and the pathogenesis of inflammatory diseases. Seminars Nephrol. 2007;27:98-114.

69. Aghdashi M, Aribi S, Salami S. Serum levels of IL-18 in Iranian females with systemic lupus erythematosus. Med Arch. 2013;67(4):237-40.

70. Dinarello CA. IL-18: A TH1-inducing, proinflammatory cytokine and new member of the IL-1 family. J Allergy Clin Immunol. 1999;103(1):11-24.

71. Jafari-Nakhjavani MR, Abedi-Azar S, Nejati B. Correlation of plasma interleukin-18 concentration and severity of renal involvement and disease activity in systemic lupus erythematosus. J Nephropathol. 2016;5(1):28.

72. Rovin $\mathrm{BH}$, et al. Plasma, urine, and renal expression of adiponectin in human systemic lupus erythematosus. Kidney Int. 2005;68(4):1825-33.

73. Loghman M, et al. Association between urinary adiponectin level and renal involvement in systemic lupus erythematous. Intern J Rheum Dis. 2016;19(7):678-84.

74. Sawalha AH, et al. Common variants within MECP2 confer risk of systemic lupus erythematosus. PLoS ONE. 2008;3(3):e1727.

75. Yang $\mathrm{T}$, et al. Overexpression of methyl-CpG binding protein 2 impairs $\mathrm{T}(\mathrm{H}) 1$ responses. Sci Transl Med. 2012;4(163):163ra158.

76. Alesaeidi S, et al. Methyl-CpG-binding protein 2 (MECP2) polymorphism in Iranian patients with systemic lupus erythematosus. Inflammation. 2015;38(6):2185-90

77. Peng S. Fas (CD95)-related apoptosis and rheumatoid arthritis. Rheumatology. 2006:45(1):26-30.

78. Kamradt T, Mitchison NA. Tolerance and autoimmunity. N Engl J Med. 2001:344(9):655-64

79. Sahebari M, et al. Correlation between serum levels of soluble fas (CD95/Apo-1) with disease activity in systemic lupus erythematosus patients in Khorasan. Iran. 2010:32:601.
80. Sahebari $\mathrm{M}$, et al Correlation between serum concentrations of soluble Fas (CD95/Apo-1) and IL-18 in patients with systemic lupus erythematosus. Rheumatol Int. 2012:32(3):601-6.

81. Hatef MR, et al. Stronger correlation between interleukin 18 and soluble fas in lupus nephritis compared with mild lupus. ISRN Rheumatol. 2013;2013:1-6.

82. Moudi B, et al. Association of FAS and FAS ligand genes polymorphism and risk of systemic lupus erythematosus. Sci World J. 2013;2013:1-6.

83. Danchenko N, Satia J, Anthony M. Epidemiology of systemic lupus erythematosus: a comparison of worldwide disease burden. Lupus. 2006;15(5):308-18.

84. Cheng J, et al. Protection from Fas-mediated apoptosis by a soluble form of the Fas molecule. Science. 1994;263(5154):1759-62.

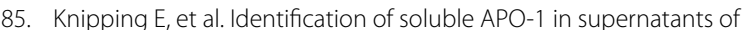
human B-and T-cell lines and increased serum levels in B-and T-cell leukemias. Blood. 1995;85:1562-9.

86. Araste JM, et al. Fas gene polymorphisms in systemic lupus erythematosus and serum levels of some apoptosis-related molecules. Immunol Invest. 2010;39(1):27-38.

87. Ferreiros-Vidal I, et al. Association of PDCD1 with susceptibility to systemic lupus erythematosus: evidence of population-specific effects. Arthritis Rheum Off J Am Coll Rheumatol. 2004;50(8):2590-7.

88. Rocha MC, et al. Genetic polymorphisms and surface expression of CTLA-4 and PD-1 on T cells of silica-exposed workers. Int J Hyg Environ Health. 2012;215(6):562-9.

89. Agata Y, et al. Expression of the PD-1 antigen on the surface of stimulated mouse T and B lymphocytes. Int Immunol. 1996;8(5):765-72.

90. Fathi $F$, et al. Effects of the programmed cell death 1 (PDCD1) polymorphisms in susceptibility to systemic lupus erythematosus. Int J Immunogenet. 2020;47(1):57-64.

91. Mahmoudi M, et al. PDCD1 single nucleotide genes polymorphisms confer susceptibility to juvenile-onset systemic lupus erythematosus. Autoimmunity. 2015;48(7):488-93.

92. Weinberg $A D$, et al. Blocking OX-40/OX-40 ligand interaction in vitro and in vivo leads to decreased $T$ cell function and amelioration of experimental allergic encephalomyelitis. J Immunol. 1999;162(3):1818-26.

93. Godfrey WR, et al. Identification of a human OX-40 ligand, a costimulator of CD4+ T cells with homology to tumor necrosis factor. J Exp Med. 1994;180(2):757-62.

94. Ito T, et al. TSLP-activated dendritic cells induce an inflammatory Thelper type 2 cell response through OX40 ligand. J Exp Med. 2005;202(9):1213-23.

95. Linton P-J, et al. Costimulation via OX40L expressed by B cells is sufficient to determine the extent of primary CD4 cell expansion and Th2 cytokine secretion in vivo. J Exp Med. 2003;197(7):875-83.

96. Chan FK-M, Siegel RM, Lenardo MJ. Signaling by the TNF receptor superfamily and T cell homeostasis. Immunity. 2000;13(4):419-22.

97. Locksley RM, Killeen N, Lenardo MJ. The TNF and TNF receptor superfamilies: integrating mammalian biology. Cell. 2001;104(4):487-501.

98. Aggarwal BB. Signalling pathways of the TNF superfamily: a doubleedged sword. Nat Rev Immunol. 2003;3(9):745-56.

99. Bradley JR, Pober JS. Tumor necrosis factor receptor-associated factors (TRAFs). Oncogene. 2001;20(44):6482-91.

100. Arch RH, Thompson CB. 4-1BB and $\mathrm{O} \times 40$ are members of a tumor necrosis factor (TNF)-nerve growth factor receptor subfamily that bind TNF receptor-associated factors and activate nuclear factor KB. Mol Cell Biol. 1998;18(1):558-65.

101. Bansal-Pakala P, Jember AG-H, Croft M. Signaling through OX40 (CD134) breaks peripheral T-cell tolerance. Nat Med. 2001;7(8):907-12.

102. Rajabi $\mathrm{P}$, et al. Altered expression of TNFSF4 and TRAF2 mRNAs in peripheral blood mononuclear cells in patients with systemic lupus erythematosus: association with atherosclerotic symptoms and lupus nephritis. Inflamm Res. 2012:61(12):1347-54.

103. Stein JV, et al. APRIL modulates B and T cell immunity. J Clin Investig 2002;109(12):1587-98.

104. Dillon SR, et al. An APRIL to remember: novel TNF ligands as therapeutic targets. Nat Rev Drug Discov. 2006;5(3):235-46.

105. Yu G, et al. APRIL and TALL-1 and receptors BCMA and TACl: system for regulating humoral immunity. Nat Immunol. 2000;1(3):252-6. 
106. Sakurai $D$, et al. TACI regulates IgA production by APRIL in collaboration with HSPG. Blood. 2007;109(7):2961-7.

107. Namazi S, et al. APRIL gene polymorphism and serum SAPRIL levels in children with systemic lupus erythematosus. Clin Rheumatol. 2017;36(4):831-6.

108. Evans MJ, et al. Estrogen decreasesin vitroapoptosis of peripheral blood mononuclear cells from women with normal menstrual cycles and decreases TNF-a production in SLE but not in normal cultures. Clin Immunol Immunopathol. 1997:82(3):258-62.

109. Lin $\mathrm{H}-\mathrm{L}$, et al. Estradiol upregulates calcineurin expression via overexpression of estrogen receptor alpha gene in systemic lupus erythematosus. Kaohsiung J Med Sci. 2011;27(4):125-31.

110. Salimi S, et al. Association between ER a polymorphisms and systemic lupus erythematosus: susceptibility and in silico analysis. Intern J Rheum Dis. 2018;21(1):214-22.

111. Salomon B, Bluestone JA. Complexities of CD28/B7: CTLA-4 costimulatory pathways in autoimmunity and transplantation. Annu Rev Immunol. 2001;19(1):225-52.

112. Gribben JG, et al. CTLA4 mediates antigen-specific apoptosis of human T cells. Proc Natl Acad Sci USA. 1995:92(3):811-5.

113. Kristiansen O, Larsen Z, Pociot F. CTLA-4 in autoimmune diseasesa general susceptibility gene to autoimmunity? Genes Immun. 2000;1 (3):170-84

114. Shojaa M, et al. Association between $318 \mathrm{C} / \mathrm{T}$ polymorphism of the CTLA-4 gene and systemic lupus erythematosus in Iranian patients. Intern J Rheum Dis. 2017;20(12):2040-4

115. Lee K-J, et al. Identification of human autoantibodies to the DNA ligase IV/XRCC4 complex and mapping of an autoimmune epitope to a potential regulatory region. J Immunol. 2002;169(6):3413-21.

116. Hung RJ, et al. Genetic polymorphisms in the base excision repair pathway and cancer risk: a HuGE review. Am J Epidemiol. 2005;162(10):925-42.

117. Caldecott KW. XRCC1 and DNA strand break repair. DNA Repair. 2003;2(9):955-69.

118. Salimi S, et al. XRCC1 Arg399GIn and Arg194Trp polymorphisms and risk of systemic lupus erythematosus in an Iranian population: a pilot study. BioMed Res Intern. 2014;2014:1-5.

119. Moghbeli $\mathrm{M}$, et al. High frequency of microsatellite instability in sporadic colorectal cancer patients in Iran. Genet Mol Res. 2011;10(4):3520-9.

120. Moghbeli M, et al. Role of hMLH1 and E-cadherin promoter methylation in gastric cancer progression. J Gastrointest Cancer. 2014;45(1):40-7.

121. Mimori T, et al. Characterization of a high molecular weight acidic nuclear protein recognized by autoantibodies in sera from patients with polymyositis-scleroderma overlap. J Clin Investig. 1981;68(3):611-20.

122. Jahantigh $\mathrm{D}$, et al. Association between functional polymorphisms of DNA double-strand breaks in repair genes XRCC5, XRCC6 and XRCC7 with the risk of systemic lupus erythematosus in South East Iran. DNA Cell Biol. 2015:34(5):360-6.

123. Saxena R, Mahajan T, Mohan C. Lupus nephritis: current update. Arthritis Res Ther. 2011:13(5):240.

124. Liu M, et al. Higher activation of the interferon-gamma signaling pathway in systemic lupus erythematosus patients with a high type I IFN score: relation to disease activity. Clin Rheumatol. 2018;37(10):2675-84.

125. El-Gohary A, et al. Serum and urinary interferon-gamma-inducible protein 10 in lupus nephritis. J Clin Lab Anal. 2016;30(6):1135-8

126. Karin N, Razon H. Chemokines beyond chemo-attraction: CXCL10 and its significant role in cancer and autoimmunity. Cytokine. 2018;109:24-8.

127. Reynolds JA, et al. Vitamin $D$ improves endothelial dysfunction and restores myeloid angiogenic cell function via reduced CXCL-10 expression in systemic lupus erythematosus. Sci Rep. 2016;6(1):1-11.

128. Abediazar $S$ et al. Serum levels of CXCL10 and vitamin D in patients with lupus nephritis. Iran J Kidney Dis 2019;13(6).

129. Mazzali M, et al. Osteopontin—a molecule for all seasons. QJM. 2002;95(1):3-13.

130. Weber GF, et al. Receptor-ligand interaction between CD44 and osteopontin (Eta-1). Science. 1996:271(5248):509-12.
131. Salimi S, et al. Association of the osteopontin rs 1126616 polymorphism and a higher serum osteopontin level with lupus nephritis. Biomed Rep. 2016:4(3):355-60.

132. Kuroiwa T, Lee E. Cellular interactions in the pathogenesis of lupus nephritis: the role of T cells and macrophages in the amplification of the inflammatory process in the kidney. Lupus. 1998;7(9):597-603.

133. Carr MW, et al. Monocyte chemoattractant protein 1 acts as a T-lymphocyte chemoattractant. Proc Natl Acad Sci. 1994;91 (9):3652-6.

134. Kelley VR, Rovin BH. Chemokines: therapeutic targets for autoimmune and inflammatory renal disease. In: Seminars in Immunopathology. Springer Science \& Business Media, Germany; 2003

135. Mirfeizi $Z$, et al. Urine monocyte chemoattractant protein-1 (UMCP-1) as a biomarker of renal involvement in systemic lupus erythematosus. Iran J Basic Med Sci. 2012:15(6):1191.

136. Bevilacqua MP, et al. Endothelial leukocyte adhesion molecule 1: an inducible receptor for neutrophils related to complement regulatory proteins and lectins. Science. 1989;243(4895):1160-5

137. Seron D, Cameron J, Haskard D. Expression of VCAM-1 in the norma and diseased kidney. Nephrol Dial Transplant. 1991;6(12):917-22.

138. Clark EA, Grabstein KH, Shu G. Cultured human follicular dendritic cells. Growth characteristics and interactions with B lymphocytes. J Immunol. 1992;148(11):3327-35.

139. Wilkinson $L$, et al. Expression of vascular cell adhesion molecule-1 in normal and inflamed synovium. Laboratory investigation. J Tech Methods Pathol. 1993;68(1):82-8.

140. Julkunen $\mathrm{H}$, et al. Raised plasma concentrations of endothelin-1 in systemic lupus erythematosus. Ann Rheum Dis. 1991:50(7):526.

141. Tam L-S, Li EK, Tomlinson B. Premature atherosclerosis in systemic lupus erythematosus: pathogenesis and therapeutic considerations. Hong Kong J Nephrol. 2006;8(2):48-54.

142. Hajialilo M, et al. Relationship between serum vascular cell adhesion molecule-1 and endothelin-1 levels with organ involvement and disease activity in systemic lupus erythematosus patients. Lupus. 2018;27(12):1918-25

143. Noroozinia F, et al. Relationship between interstitial CD34 positive cells and active phase of lupus nephritis. Eur J Rheumatol. 2018;5(4):254

144. Mok CC. Biomarkers for lupus nephritis: a critical appraisal. BioMed Res Intern. 2010:2010:1-11.

145. Mishra J, et al. Identification of neutrophil gelatinase-associated lipocalin as a novel early urinary biomarker for ischemic renal injury. J Am Soc Nephrol. 2003;14(10):2534-43.

146. Lee $\mathrm{S}$, et al. Lipocalin-2 Is a chemokine inducer in the central nervous system: role of chemokine ligand 10 (CXCL10) in lipocalin-2-induced cell migration. J Biol Chem. 2011;286(51):43855-70.

147. Sharifipour $F$, et al. Association of urinary lipocalin-2 with lupus nephritis. Iran J Basic Med Sci. 2013;16(9):1011.

148. Jacobsen JP, Ullman S, Junker P, Voss A, Rasmussen JM, Tarp U, Poulsen LH, van Overeem Hansen G, Skaarup B, Hansen TM, Pødenphant J, Halberg PS. Mortality and causes of death of 513 Danish patients with systemic lupus erythematosus. Scand J Rheumatol. 1999;28(2):75-80

149. Bellomio V, et al. Systemic lupus erythematosus: mortality and survival in Argentina. A multicenter study. Lupus. 2000;9(5):377-81.

150. Ward MM. Premature morbidity from cardiovascular and cerebrovascular diseases in women with systemic lupus erythematosus. Arthritis Rheum Off J Am Coll Rheumatol. 1999:42(2):338-46.

151. Gibbons GH, Dzau VJ. The emerging concept of vascular remodeling. N Engl J Med. 1994;330(20):1431-8.

152. Galis ZS, Khatri JJ. Matrix metalloproteinases in vascular remodeling and atherogenesis: the good, the bad, and the ugly. Circ Res. 2002;90(3):251-62.

153. Saedi M, et al. Matrix metalloproteinas-9 functional promoter polymorphism 1562C > T increased risk of early-onset coronary artery disease. Mol Biol Rep. 2012;39(1):555-62.

154. Füth $R$, et al. Soluble P-selectin and matrix metalloproteinase 2 levels are elevated in patients with diastolic dysfunction independent of glucose metabolism disorder or coronary artery disease. Exp Clin Cardiol. 2009;14(3):e76.

155. Kodali R, et al. Chemokines induce matrix metalloproteinase-2 through activation of epidermal growth factor receptor in arterial smooth muscle cells. Cardiovasc Res. 2006;69(3):706-15. 
156. Bahrehmand F, et al. Matrix metalloproteinase-2 functional promoter polymorphism G1575A is associated with elevated circulatory MMP-2 levels and increased risk of cardiovascular disease in systemic lupus erythematosus patients. Lupus. 2012;21(6):616-24.

157. Deng $Y$, et al. MicroRNA-3148 modulates allelic expression of toll-like receptor 7 variant associated with systemic lupus erythematosus. PLoS Genet. 2013;9(2):e1003336.

158. Laska MJ, et al. Polymorphisms within Toll-like receptors are associated with systemic lupus erythematosus in a cohort of Danish females. Rheumatology. 2014;53(1):48-55.

159. Pacheco GV, et al. Expression of TLR-7, MyD88, NF-kB, and INF-a in B lymphocytes of Mayan women with systemic lupus erythematosus in Mexico. Front Immunol. 2016;7:22

160. Rahman AH, Eisenberg RA. The role of toll-like receptors in systemic lupus erythematosus. In: Springer seminars in immunopathology. Springer, Berlin; 2006

161. Rottman J, Willis C. Mouse models of systemic lupus erythematosus reveal a complex pathogenesis. Vet Pathol. 2010;47(4):664-76.

162. Ma K, et al. Roles of B cell-intrinsic TLR signals in systemic lupus erythe matosus. Int J Mol Sci. 2015:16(6):13084-105

163. Kawasaki T, et al. The second messenger phosphatidylinositol-5-phosphate facilitates antiviral innate immune signaling. Cell Host Microbe. 2013;14(2):148-58.

164. Fischer M, Ehlers M. Toll-like receptors in autoimmunity. Ann NY Acad Sci. 2008;1143(1):21-34.

165. Kontaki E, Boumpas DT. Innate immunity in systemic lupus erythematosus: sensing endogenous nucleic acids. J Autoimmun. 2010;35(3):206-11.

166. Mora JR, Iwata M, Von Andrian UH. Vitamin effects on the immune system: vitamins A and D take centre stage. Nat Rev Immunol. 2008:8(9):685-98.

167. Yazdanpanah E, et al. Vitamin D3 alters the expression of toll-like receptors in peripheral blood mononuclear cells of patients with systemic lupus erythematosus. J Cell Biochem. 2017;118(12):4831-5.

168. Mackay F, et al. BAFF AND APRIL: a tutorial on B cell survival. Annu Rev Immunol. 2003;21(1):231-64.

169. Mortezagholi S, et al. Evaluation of PBMC distribution and TLR9 expression in patients with systemic lupus erythematosus. Iran J Allergy Asthma Immunol. 2016;15(3):229-36.

170. Namjou B, et al. PTPN22 association in systemic lupus erythematosus (SLE) with respect to individual ancestry and clinical sub-phenotypes. PLOS ONE. 2013:8(8):e69404.

171. Wang Y, et al. The autoimmunity-associated gene PTPN22 potentiates toll-like receptor-driven, type 1 interferon-dependent immunity. Immunity. 2013;39(1):111-22.

172. Ladner MB, et al. Association of the single nucleotide polymorphism C1858T of the PTPN22 gene with type 1 diabetes. Hum Immunol. 2005;66(1):60-4.

173. Bahrami T, et al. Association of PTPN22 gene polymorphisms with susceptibility to juvenile idiopathic arthritis in Iranian population. Fetal Pediatric Pathol. 2017:36(1):42-8.

174. Aslani S, et al. Lack of association between STAT4 single nucleotide polymorphisms and Iranian juvenile rheumatoid arthritis patients. Fetal Pediatric Pathol. 2017;36(3):177-83.

175. Bahrami T, et al. PTPN22 gene polymorphisms in pediatric systemic lupus erythematosus. Fetal Pediatric Pathol. 2020;39(1):13-20.

176. Nagy G, et al. Central role of nitric oxide in the pathogenesis of rheumatoid arthritis and sysemic lupus erythematosus. Arthritis Res Ther. 2010;12(3):210.

177. Nagy G, Koncz A, Perl A. T cell activation-induced mitochondrial hyperpolarization is mediated by $\mathrm{Ca}^{2+}$-and redox-dependent production of nitric oxide. J Immunol. 2003:171(10):5188-97.

178. Kim Y-M, Bombeck CA, Billiar TR. Nitric oxide as a bifunctional regulator of apoptosis. Circ Res. 1999:84(3):253-6.

179. Stark RJ, et al. Endothelial nitric oxide synthase modulates Toll-like receptor 4-mediated IL-6 production and permeability via nitric oxideindependent signaling. FASEB J. 2018;32(2):945-56.

180. Nagy $\mathrm{G}$, et al. Nitric oxide-dependent mitochondrial biogenesis generates $\mathrm{Ca}^{2+}$ signaling profile of lupus T cells. J Immunol. 2004;173(6):3676-83.
181. Nagy G, et al. Mitochondrial signal transduction abnormalities in systemic lupus erythematosus. Curr Immunol Rev. 2005;1(1):61-7.

182. Yaghmaei M, et al. Endothelial nitric oxide synthase gene Glu298Asp polymorphism and risk of preeclampsia in South East of Iran. Afr J Biotech. 2011:10(52):10712-7.

183. Song J, et al. Clinical associations of anti-endothelial cell antibodies in patients with systemic lupus erythematosus. Rheumatol Int. 2000;20(1):1-7.

184. Bordron A, et al. Functional heterogeneity of anti-endothelial cell antibodies. Clin Exp Immunol. 2001;124(3):492-501.

185. Sandoughi $M$, et al. Association of eNOS gene polymorphisms and systemic lupus erythematosus in southeast Iran. Intern J Rheum Dis. 2016;19(6):606-12.

186. Rider J, et al. Human cytomegalovirus infection and systemic lupus erythematosus. Clin Exp Rheumatol. 1997;15(4):405-9.

187. Ben Mansour $\mathrm{R}$, et al. Enhanced reactivity to malondialdehydemodified proteins by systemic lupus erythematosus autoantibodies. Scand J Rheumatol. 2010;39(3):247-53.

188. Wang $G$, et al. Markers of oxidative and nitrosative stress in systemic lupus erythematosus: correlation with disease activity. Arthritis Rheum. 2010;62(7):2064-72.

189. Alves JD, Grima B. Oxidative stress in systemic lupus erythematosus and antiphospholipid syndrome: a gateway to atherosclerosis. Curr Rheumatol Rep. 2003:5(5):383-90.

190. Mannervik B. The isoenzymes of glutathione transferase. Adv Enzymol Relat Areas Mol Biol. 1985;57:357-417.

191. Mannervik B, et al. Nomenclature for human glutathione transferases. Biochem J. 1992;282(Pt 1):305.

192. Barnes PJ. Reactive oxygen species and airway inflammation. Free Radical Biol Med. 1990;9(3):235-43.

193. Ryberg D, et al. Genotypes of glutathione transferase $\mathrm{M} 1$ and $\mathrm{P} 1$ and their significance for lung DNA adduct levels and cancer risk. Carcinogenesis. 1997;18(7):1285-9.

194. Salimi S, et al. Combination effect of GSTM1, GSTT1 and GSTP1 polymorphisms and risk of systemic lupus erythematosus. Iran J Public Health. 2015:44(6):814.

195. Bahrehmand F, et al. Synergistic effects of BuChE non-UU phenotype and paraoxonase (PON1) $55 \mathrm{M}$ allele on the risk of systemic lupus erythematosus: influence on lipid and lipoprotein metabolism and oxidative stress, preliminary report. Lupus. 2014;23(3):263-72.

196. Tewthanom K. Correlation of lipid peroxidation and glutathione levels with severity of systemic lupus erythematosus: a pilot study from single center. J Pharm Pharm Sci. 2008;11(3):30-4.

197. Bahrehmand F, et al. Paraoxonase (PON1) 55 polymorphism and association with systemic lupus erythematosus. Iran J Allergy Asthma Immunol. 2013;2013:211-9.

198. Song L-J, et al. The positive correlations of apolipoprotein E with disease activity and related cytokines in systemic lupus erythematosus. Diagn Pathol. 2013;8(1):175

199. Tanhapour M, et al. Synergism between apolipoprotein E $\mathcal{E} 4$ allele and paraoxonase (PON1) 55-M allele is associated with risk of systemic lupus erythematosus. Clin Rheumatol. 2018;37(4):971-7.

200. Stypińska B, Paradowska-Gorycka A. Cytokines and MicroRNAs as candidate biomarkers for systemic lupus erythematosus. Int J Mol Sci. 2015;16(10):24194-218.

201. Zeng J, et al. Novel biomarkers for systemic lupus erythematosus. Biomarkers Med. 2017;11(8):677-86.

202. Dai Y, et al. Microarray analysis of microRNA expression in peripheral blood cells of systemic lupus erythematosus patients. Lupus. 2007:16(12):939-46.

203. Khoshmirsafa M, et al. Elevated expression of miR-21 and miR-155 in peripheral blood mononuclear cells as potential biomarkers for lupus nephritis. Intern J Rheum Dis. 2019;22(3):458-67.

204. Zhao X, et al. MicroRNA-125a contributes to elevated inflammatory chemokine RANTES levels via targeting KLF13 in systemic lupus erythematosus. Arthritis Rheum. 2010;62(11):3425-35.

205. Ding $S$, et al. Decreased microRNA-142-3p/5p expression causes CD4+ T cell activation and B cell hyperstimulation in systemic lupus erythematosus. Arthritis Rheum. 2012;64(9):2953-63. 
206. Vahed SZ, et al. Altered levels of immune-regulatory microRNAs in plasma samples of patients with lupus nephritis. Biolmpacts $\mathrm{BI}$ 2018;8(3):177.

207. Lu Z, et al. MicroRNA-21 promotes cell transformation by targeting the programmed cell death 4 gene. Oncogene. 2008;27(31):4373-9.

208. Xiao C, et al. MiR-150 controls B cell differentiation by targeting the transcription factor c-Myb. Cell. 2007;131(1):146-59.

209. Nakhjavani M et al. Plasma levels of miR-21, miR-150, miR-423 in patients with lupus nephritis. Iran J Kidney Dis. 2019:13(3).

210. French AR, Yokoyama WM. Natural killer cells and autoimmunity. Arthritis Res Ther. 2003;6(1):8.

211. Wood SM, Ljunggren H-G, Bryceson YT. Insights into NK cell biology from human genetics and disease associations. Cell Mol Life Sci. 2011;68(21):3479.

212. Khakoo SI, Carrington M. KIR and disease: a model system or system of models? Immunol Rev. 2006;214(1):186-201.
213. Kulkarni S, Martin MP, Carrington M. The Yin and Yang of HLA and KIR in human disease. In: Seminars in immunology. Elsevier; 2008.

214. Akhtari $M$, et al. Analysis of killer cell immunoglobulin-like receptors and their human leukocyte antigen-ligands gene polymorphisms in Iranian patients with systemic lupus erythematosus. Lupus. 2016;25(11):1244-53.

215. Rezaei $Y Z$, et al. Association of HLA-DQB1 allelic sequence variation with susceptibility to systemic lupus erythematosus. Iran J Allergy Asthma Immunol. 2008;7:91-5.

\section{Publisher's Note}

Springer Nature remains neutral with regard to jurisdictional claims in published maps and institutional affiliations.
Ready to submit your research? Choose BMC and benefit from:

- fast, convenient online submission

- thorough peer review by experienced researchers in your field

- rapid publication on acceptance

- support for research data, including large and complex data types

- gold Open Access which fosters wider collaboration and increased citations

- maximum visibility for your research: over $100 \mathrm{M}$ website views per year

At BMC, research is always in progress.

Learn more biomedcentral.com/submissions 